\title{
Sistem Pakar Diagnosis Penyakit Gigi dengan Metode Breadth First Search berbasis Instant Messaging LINE Messenger
}

\author{
Kadek Darmaastawan ${ }^{1}$, Putu Lanang Bagus Suputra Jaya Amertha ${ }^{2}$, Lie Jasa ${ }^{3}$
}

[Submission: 31-05-2020, Accepted: 08-03-2021]

\begin{abstract}
Toothache is a disease commonly experienced by humans, therefore must be treated immediately to prevent serious impact. One of the initial treatments is to consult a dental expert. Current technological developments have been able to transform an expert's knowledge into a digital form called an expert system for easy and fast access. Currently, most expert systems are based on the web and Android/iOS platforms. The development of an expert system based on web applications or Android/iOS faces several challenges. The challenge is that it requires a lot of development time and costs because it has to develop an interface and requires a server with good performance. The challenge faced from the user's side is that more storage space is needed to install an expert system on smartphones. The solution proposed in this study is to develop an expert dental disease diagnosis system using the Breadth First Search Method based on instant messaging. One of the most popular instant messaging in Indonesia is LINE Messenger. This research succeeded in developing a dental disease diagnosis expert system based on LINE Messenger that is easily accessible and capable of diagnosing diseases with an accuracy rate of $90.9 \%$.
\end{abstract}

Intisari- Sakit gigi merupakan penyakit yang umum dialami oleh manusia, oleh karena itu harus ditangani dengan cepat agar tidak menimbulkan dampak serius. Salah satu penanganan awal adalah dengan berkonsultasi dengan pakar penyakit gigi. Perkembangan teknologi saat ini telah mampu mengkonversi pengetahuan seorang pakar ke dalam bentuk digital yang disebut dengan sistem pakar sehingga mudah dan cepat diakses. Sistem pakar yang sudah banyak dikembangkan saat ini secara umum berbasis aplikasi web maupun Android/iOS. Pengembangan sistem pakar berbasis aplikasi web atau Android/iOS menghadapi beberapa kesulitan. Kesulitan tersebut adalah membutuhkan waktu dan biaya pengembangan yang tidak sedikit karena harus mengembangkan antarmuka dan membutuhkan server dengan performa baik. Kesulitan yang dihadapi dari sisi pengguna adalah diperlukan ruang penyimpanan yang lebih agar dapat memasang aplikasi sistem pakar di smartphone. Solusi yang diberikan adalah

\footnotetext{
${ }^{1}$ Mahasiswa, Program Pasca Sarjana, Manajemen Sistem Informasi dan Komputer Fakultas Teknik Universitas Udayana, Jln. Pulau Tarakan No. 19, Denpasar, Bali 80114 INDONESIA (tlp: 081237760468; e-mail: kadek_darmaastawan@yahoo.co.id)

${ }^{2}$ Mahasiswa, Program Pasca Sarjana, Manajemen Sistem Informasi dan Komputer Fakultas Teknik Universitas Udayana, Jln. Pulau Roti Gang Roti Permai No. A/2, Denpasar, Bali 80222 INDONESIA (tlp: $\quad$ 08993150517; e-mail: putulanangamertha@gmail.com)

${ }^{3}$ Dosen, Pasca Sarjana Jurusan Teknik Elektro Fakultas Teknik Universitas Udayana, Jln. Panglima Besar Sudirman Denpasar Bali 80234 INDONESIA; e-mail: liejasa@unud.ac.id)
}

mengembangkan sistem pakar diagnosis penyakit gigi dengan Metode Breadth First Search berbasis aplikasi instant messaging. Salah satu aplikasi instant messaging yang populer di indonesia adalah LINE Messenger. Penelitian ini berhasil mengembangkan sistem pakar diagnosis penyakit gigi berbasis instant messaging LINE Messenger yang mudah diakses dan mampu mendiagnosis penyakit dengan tingkat akurasi sebesar $\mathbf{9 0 , 9 \%}$.

Kata Kunci- Sistem Pakar, Instant Messaging, Breadth First Search, LINE Messenger.

\section{PENDAHULUAN}

Perkembangan teknologi yang pesat saat ini telah menghasilkan begitu banyak perangkat lunak atau sistem yang dapat memudahkan kehidupan manusia, salah satunya adalah artificial intelligence. Artificial intelligence merupakan agen cerdas, baik perangkat lunak maupun mesin, yang dapat diterapkan di hampir setiap bidang pekerjaan manusia, mulai dari pekerjaan kasar hingga perhitungan canggih [1]. Salah satu contoh dari artificial intelligence adalah sistem pakar. Sistem pakar merupakan artificial intelligence yang mengimplementasikan pengetahuan dari seorang pakar. Sistem pakar dapat digunakan untuk berbagai hal, salah satunya adalah peramalan [2]. Peramalan dilakukan dengan menganalisis gejala atau fakta yang sudah terjadi sebelumnya dan secara berulang-ulang dengan menggunakan metode tertentu sehingga dapat menghasilkan sebuah kesimpulan yang tepat [3]. Sistem pakar dibuat karena adanya permasalahan dari seorang pakar, yaitu seorang pakar tidak selalu tersedia setiap saat, sehingga dapat menghambat dalam pengambilan keputusan [4]. Lebih lanjut, pada penelitian [5] disebutkan bahwa sistem pakar merupakan cabang dari artificial intelligence yang memungkinkan masyarakat untuk berinteraksi dengan komputer sehingga dapat memecahkan masalah pada bidang tertentu.

Salah satu contoh penerapan sistem pakar dibahas pada penelitian [6], yaitu sistem pakar untuk mendeteksi penyakit gigi dengan menggunakan Metode Certainty Factor. Sistem pakar untuk mendeteksi penyakit gigi tersebut dibangun pada platform Android, sehingga pengguna dapat menggunakan sistem pakar tersebut dimana saja melalui smartphone Android. Kelemahan yang dihadapi jika menerapkan sistem berbasis Android adalah adanya masalah baik di sisi pengembang sistem maupun pengguna sistem. Masalah yang dihadapi dari sisi pengembang adalah selain membangun sisi server untuk pengolahan data, pengembang juga harus membangun user interface untuk menampilkan data ke pengguna, sehingga memerlukan biaya, waktu, dan tenaga

p-ISSN:1693 - 2951; e-ISSN: 2503-2372 
yang lebih banyak. Masalah dari sisi pengguna adalah diperlukannya ruang penyimpanan tambahan pada smartphone agar dapat memasang aplikasi sistem pakar. Permasalahan tersebut dapat diselesaikan dengan memanfaatkan Application Programming Interface (API) dari aplikasi instant messaging untuk menerima data dari pengguna dan meneruskannya ke sisi server untuk diolah lebih lanjut, sehingga tidak perlu membangun user interface tambahan untuk memperoleh data dari pengguna dan menampilkan data ke pengguna.

Instant messaging atau aplikasi chatting merupakan salah satu layanan komunikasi yang memanfaatkan internet sehingga setiap orang dapat dengan mudah berkomunikasi satu sama lain [7]. Aplikasi instant messaging yang tersedia saat ini antara lain LINE Messenger, Telegram, WhatsApp, Facebook Messenger, dan sebagainya. Aplikasi instant messaging merupakan layanan komunikasi yang cukup populer dikalangan masyarakat umum, terbukti pada data statistik [8], tentang pengguna aktif jejaring sosial diseluruh dunia hingga bulan April 2020. Suvei lainnya dari DailySocial [9] yang membahas tentang penggunaan instant messaging di tahun 2017 yang diikuti oleh 1.022 responden yang merupakan masyarakat Indonesia. Hasil survei tersebut menunjukkan bahwa $85.82 \%$ menggunakan LINE Messenger.

LINE Messenger merupakan aplikasi layanan pengiriman pesan gratis yang tersedia dalam berbagai platform [10]. Dan memiliki fitur bot API [11]. Penggunaan bot LINE Messenger sudah banyak diterapkan pada berbagai bidang [12], [13]. Fitur bot pada aplikasi instant messaging LINE Messenger akan digunakan sebagai antarmuka bagi pengguna dalam berkonsultasi dengan sistem pakar penelitian ini.

Penelitian ini mengembangkan sebuah sistem pakar untuk mendeteksi penyakit gigi dengan menggunakan Metode Breadth First Search (BFS) berbasis instant messaging LINE Messenger dengan memanfaatkan penelitian-penelitian terdahulu terkait pemanfaatan API instant messaging dan Metode BFS.

\section{KAJIAN PUSTAKA}

Kajian pustaka membahas mengenai literatur yang menunjang kegiatan penelitian.

\section{A. Pemanfaatan API Instant Messaging}

Beberapa penelitian terdahulu memanfaatkan API instant messaging sebagai media transportasi data [12]-[16]. Penelitian [14] mengajukan sebuah framework yang memiliki kemampuan untuk mengubah sistem informasi yang sudah ada menjadi berbasis chatting dengan memanfaatkan aplikasi instant messaging lengkap dengan Role-based Access Control (RBAC), session, validasi, dan interaksi alami dengan menggunakan Bahasa Indonesia. Penelitian lebih lanjut membahas mengenai pemanfaatan API LINE Messenger sebagai transport layer sehingga dapat bertukar pesan dengan instant messaging lain, yaitu Telegram dan XMPP [12]. Pemanfaatan API LINE Messenger lainnya adalah sebagai media pembelajaran tentang sejarah Bali [13]. Chatbot tersebut memanfaatkan API dari LINE Messenger untuk menerima data dari pengguna yang berupa pertanyaan dalam bentuk pesan teks yang kemudian dicocokkan dengan basis pengetahuan tentang sejarah Bali untuk menemukan respon terbaik. Penelitian [15] membangun aplikasi Internet of Things yang memanfaatkan API Telegram dalam mebangun sistem perpustakaan berbasis RFID, dimana API Telegram digunakan sebagai media untuk memfasilitasi pengguna seperti notifikasi, riwayat peminjaman buku, dan sebagainya.

Pemanfaatan API lainnya adalah API Twitter yang dimanfaatkan untuk membangun sebuah layanan yang disebut dengan T411 [16]. T411 merupakan layanan yang dapat mengubah akun Twitter menjadi auto-responder, sehingga akun Twitter dapat menerima perintah yang berupa kode tertentu melalui mention atau direct message Twitter dan memberikan respon yang sesuai.

\section{B. LINE Messenger}

LINE Messenger merupakan aplikasi instant messaging gratis buatan jepang yang dipublikasikan pada tahun 2011 [17]. Aplikasi client LINE Messenger tersedia dalam berbagai platform seperti IOS, Android, MacOS, Windows Phone, dan Windows [10]. LINE Messenger memiliki fitur bot API yang dapat digunakan dengan gratis oleh pengembang pihak ketiga dalam membuat sebuah aplikasi [11] [18].

\section{Sistem Pakar}

Penelitian terkait dengan sistem pakar sudah pernah dilakukan sebelumnya [19], [20], [29], [21]-[28], namun penelitian tentang penerapan instant messaging LINE Messenger pada sistem pakar dengan Metode BFS belum pernah dilakukan. Sistem pakar adalah sebuah cabang dari computer science yang dikenal dengan istilah artificial intelligence yang digunakan oleh manusia untuk mempermudah pekerjaan tertentu [19]. Pengetahuan seorang pakar merupakan dasar dari sistem pakar dalam memecahkan masalah di bidang tertentu [20]. Sistem pakar tidak menggantikan peran manusia, namun menyajikan pengetahuan manusia ke dalam sistem, sehingga dapat dengan mudah digunakan oleh banyak orang [30]. Sistem pakar, secara umum memiliki tiga pelaku utama, yaitu pengguna, seorang pakar, dan knowledge engineer, yang mengubah pengetahuan dari seorang pakar ke dalam bentuk aturan yang dapat dimengerti oleh sistem. Sistem pakar juga memiliki tiga komponen utama, yaitu user interface, basis pengetahuan, dan mesin inferensi, untuk gambaran lebih jelas dapat dilihat pada Gambar 1: [21]-[23].

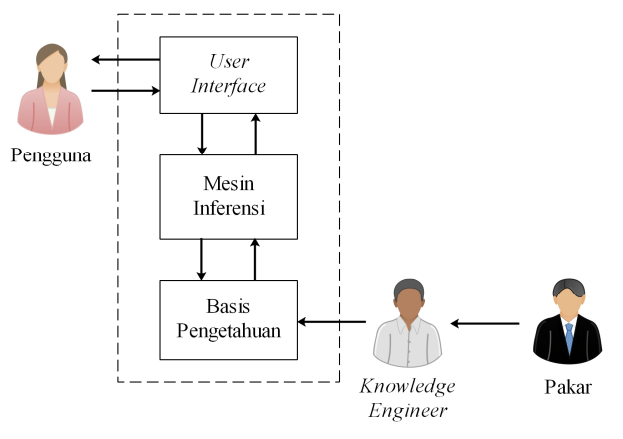

Gambar 1: Pelaku dan komponen utama sistem pakar

1) User Interface: User interface adalah bagian dari sistem pakar yang berhubungan secara langsung dengan pengguna sistem pakar. Pengguna dapat menerima pertanyaan maupun 
respon dari sistem pakar serta memberikan jawaban ke sistem pakar melalui user interface.

2) Basis Pengetahuan: Basis pengetahuan berisi fakta dan aturan yang berdasarkan pada pengetahuan seorang pakar pada suatu bidang tertentu. Knowledge engineer bertugas untuk mengkonversikan pengetahuan dari pakar ke bentuk basis pengetahuan karena pada umumnya seorang pakar tidak memiliki kemampuan di bidang pemrograman.

3) Mesin Inferensi: Mesin inferensi adalah perangkat lunak yang digunakan untuk mencocokkan data input pengguna dengan data yang berada di basis pengetahuan. Mesin inferensi memiliki tujuan untuk memperoleh respon yang akan dikirim ke pengguna berdasarkan data input. Hal tersebut dilakukan dengan aturan inferensi, seperti aturan if kondisi then kesimpulan.

\section{Breadth First Search}

Penerapan Metode BFS pada sistem pakar hardware komputer dilakukan pada penelitian [25], [27]-[29], yang menyebutkan bahwa, Metode BFS adalah metode pencarian pada pohon keputusan hingga ke akar-akarnya hingga tidak memiliki akar lagi. Metode BFS juga dapat diterapkan pada sebuah game seperti pada penelitian [31], [32].

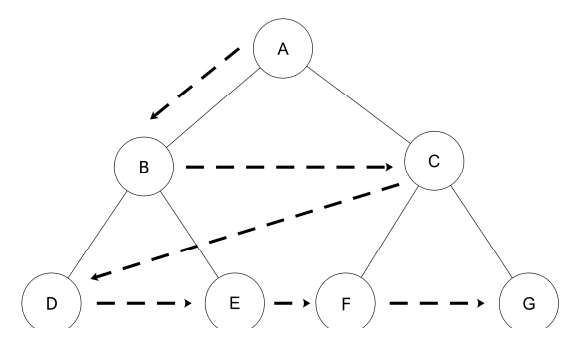

Gambar 2: Breadth First Search

Metode BFS merupakan teknik penelusuran pohon keputusan untuk memperoleh suatu kesimpulan [24], [25]. Metode BFS akan melakukan penelusuran per tingkat, dimana proses diawali dengan menelusuri tingkat pertama pada pohon keputusan, kemudian dilanjutkan ke tingkat kedua, dan seterusnya hingga mencapai kesimpulan [31], [33], [34]. Gambar 2: menyajikan alur secara umum dari Metode BFS dalam menelusuri pohon keputusan yang ditunjukkan oleh garis putus-putus.

\section{Metode Perancangan}

Penelitian ini membangun sebuah sistem pakar diagnosis penyakit gigi berbasis instant messaging dengan menerapkan model pengembangan sistem Design Science Research Methodology (DSRM) yang terdiri dari tahap formulasi masalah, persiapan bahan studi untuk solusi alternatif, perancangan dan pengembangan, implementasi, evaluasi dan pelaporan [14].

\section{A. Gambaran Umum Sistem}

Gambar 3: menyajikan gambaran umum dari alur sistem yang dibangun.

Kadek Darmaastawan: Sistem Pakar Diagnosis Penyakit...

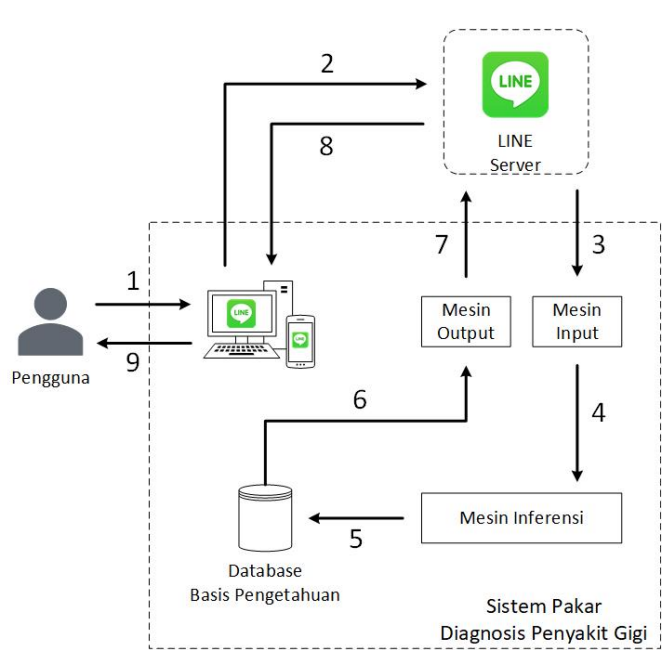

Gambar 3: Gambaran umum sistem

Sistem pakar yang dibangun pada penelitian ini memanfaatkan LINE Messenger sebagai user interface. LINE Messenger digunakakan karena API LINE Messenger dapat digunakan secara gratis. Alasan lain menggunakan LINE Messenger adalah karena LINE Messenger merupakan salah satu instant messaging yang banyak digunakan di Indonesia [9]. Sistem pakar memiliki alur sistem yang bersifat berulang. Perulangan yang terjadi pada sistem berupa interaksi atau percakapan antara pengguna dan sistem dalam mencari kesimpulan berdasarkan fakta. Berikut penjelasan lebih rinci mengenai gambaran umum dari sistem pakar yang dibangun:

- Garis 1 pada Gambar 3: merupakan proses dimana pengguna mengirim pesan teks melalui aplikasi instant messaging LINE Messenger pada komputer ataupun smartphone,

- Garis 2 pada Gambar 3: menunjukkan pesan teks yang dikirim oleh pengguna diteruskan ke LINE Messenger server. Pesan teks mengalami pengolahan pada LINE Messenger server sehingga mengalami perubahan bentuk menjadi JSON dengan tambahan informasi seperti identifier pengirim, isi pesan, waktu pesan terkirim, dan sebagainya,

- Garis 3 pada Gambar 3: menunjukkan. data pesan teks dalam bentuk JSON yang diteruskan ke sistem. Sistem akan melakukan parsing terhadap data JSON yang diterima untuk memperoleh isi pesan, identifier pengguna, dan sebagainya

- Garis 4 pada Gambar 3: menunjukkan isi pesan yang diperoleh diteruskan ke mesin inferensi untuk diolah lebih lanjut,

- Garis 5 pada Gambar 3: merupakan proses pencocokkan isi pesan dan penelusuran basis pengetahuan sehingga dapat diperoleh respon yang sesuai dengan isi pesan dari pengguna,

- Garis 6 pada Gambar 3: menunjukkan respon yang telah berhasil diperoleh dijadikan nilai output oleh sistem dan siap dikirim kembali ke pengguna,

- Garis 7 pada Gambar 3: menunjukkan sistem pakar mengirim output yang berupa respon ke pengguna p-ISSN: 1693 - 2951; e-ISSN: 2503-2372 
melalui LINE Messenger server dengan memanfaatkan identifier pengguna,

- Garis 8 pada Gambar 3: menunjukkan respon pada LINE Messenger server diteruskan ke perangkat pengguna,

- Garis 9 pada Gambar 3: merupakan respon yang telah berhasil ditampilkan ke pengguna melalui aplikasi instant messaging LINE Messenger.

Proses yang terjadi akan mengalami perulangan sehingga membentuk percakapan antara pengguna dengan sistem pakar yang bertujuan untuk memberikan solusi dari masalah yang dihadapi pengguna.

\section{B. Basis Pengetahuan}

Data gejala dan penyakit gigi yang digunakan sebagai dasar basis pengetahuan untuk sistem pakar pada penelitian ini diambil pada penelitian [6]. Sistem pakar yang dibangun memiliki 28 gejala dari penyakit gigi yang dapat dipilih oleh pengguna yang digunakan oleh sistem pakar untuk menentukan penyakit gigi. Data gejala dari penyakit gigi disajikan pada Tabel 1:

TABEL I

DATA GEJALA

\begin{tabular}{|c|l|}
\hline $\begin{array}{c}\text { Kode } \\
\text { Gejala }\end{array}$ & \multicolumn{1}{|c|}{ Nama Gejala } \\
\hline G01 & Susah mengunyah \\
\hline G02 & Gusi membengkak atau memerah \\
\hline G03 & Rahang membengkak \\
\hline G04 & Demam \\
\hline G05 & Nyeri di sekitar gusi (disentuh maupun tidak disentuh) \\
\hline G06 & Gusi atau gigi bernanah \\
\hline G07 & Kelenjar getah bening membengkak \\
\hline G08 & Merasakan sakit ketika membuka mulut \\
\hline G09 & Sakit gigi atau berdenyut \\
\hline G10 & Gigi lebih sensitif \\
\hline G11 & Gusi mudah berdarah \\
\hline G12 & Luka atau kantung di antara gigi dan gusi \\
\hline G13 & Sensitif terhadap rasa manis \\
\hline G14 & Bentuk gusi bundar \\
\hline G15 & Gigi tidak tumbuh sebagian atau semua (gigi susu atau \\
& permanen) \\
\hline G16 & Bentuk gigi tampak terkikis \\
\hline G17 & Rasa sakit pada telinga \\
\hline G18 & Insomnia atau merasa tidak nyaman \\
\hline G19 & Konsistensi gusi lunak \\
\hline G20 & Pipi membengkak \\
\hline G21 & Noda putih atau kecoklatan pada permukaan gigi \\
\hline G22 & Permukaan gigi kasar \\
\hline G23 & Gigi terlihat lebih panjang dari biasanya \\
\hline G24 & Gigi goyah \\
\hline G25 & Terdapat retakan pada gigi \\
\hline G26 & Keberadaan gigi yang patah \\
\hline G27 & Dingin, manis, atau masam menyebabkan rasa sakit \\
\hline G28 & Terdapat lubang pada gigi \\
\hline Sistem & pakar yang dibangun pada penelitian ini \\
\hline
\end{tabular}

Sistem pakar yang dibangun pada penelitian ini memiliki 10 penyakit gigi. Data penyakit gigi disajikan pada Tabel 2 :

TABEL II

DATA PENYAKIT

\begin{tabular}{|c|c|}
\hline $\begin{array}{c}\text { Kode } \\
\text { Penyakit }\end{array}$ & Nama Penyakit \\
\hline P01 & Abscess Periodontal \\
\hline
\end{tabular}

\begin{tabular}{|l|l|}
\hline P02 & Abscess Periapical \\
\hline P03 & Anodontia \\
\hline P04 & Abrasi gigi \\
\hline P05 & Bruxism \\
\hline P06 & Gingivitis \\
\hline P07 & Purulent gigi \\
\hline P08 & Gigi berlubang \\
\hline P09 & Gigi patah \\
\hline P10 & Periodontitis \\
\hline
\end{tabular}

Aturan yang dibentuk berdasarkan data gejala dan data penyakit disajikan pada Tabel 3:

TABEL IIII

RULE

\begin{tabular}{|l|c|c|c|c|c|c|c|c|c|c|}
\hline & P1 & P2 & P3 & P4 & P5 & P6 & P7 & P8 & P9 & P10 \\
\hline G01 & $*$ & $*$ & & & $*$ & & & & & \\
\hline G02 & $*$ & & & & & $*$ & & & & \\
\hline G03 & & $*$ & & & & & & & & \\
\hline G04 & & $*$ & & & & & $*$ & & & \\
\hline G05 & & & & & & & & & & $*$ \\
\hline G06 & $*$ & & & & & & $*$ & & & $*$ \\
\hline G08 & $*$ & $*$ & & & & & & & & \\
\hline G09 & & $*$ & & & & & $*$ & & & \\
\hline G10 & & & & $*$ & & $*$ & & & & \\
\hline G11 & & & & & & & & & \\
\hline G12 & & & & & & & & & & $*$ \\
\hline G13 & & & & & $*$ & & & & & \\
\hline G14 & & & & & & $*$ & & & & \\
\hline G15 & & & $*$ & & & & & & & \\
\hline G16 & & & $*$ & & & & & & \\
\hline G17 & & & & $*$ & & & & & \\
\hline G18 & & & & & $*$ & & & & & \\
\hline G19 & & & & & $*$ & & & & \\
\hline G20 & & & & & & $*$ & & & \\
\hline G21 & & & & & & & $*$ & & \\
\hline G22 & & & & & & & $*$ & & \\
\hline G23 & & & & & & & & & & $*$ \\
\hline G24 & & & & & & & & & $*$ \\
\hline G25 & & & & & & & & $*$ & \\
\hline G26 & & & & & & & & $*$ & \\
\hline G27 & & & & & & & & & $*$ & \\
\hline G28 & & & & & & & & & $*$ & \\
\hline
\end{tabular}

Aturan yang dibentuk dapat direpresentasikan ke dalam bentuk pohon keputusan seperti yang dapat dilihat pada Gambar 4: 


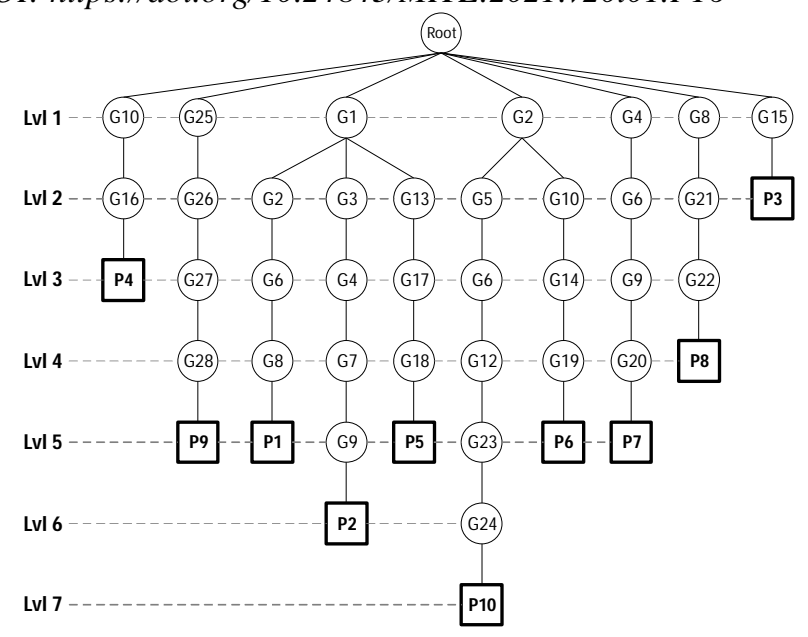

Gambar 4: Pohon Keputusan

\section{Cara Kerja Breadth First Search pada Sistem}

Metode BFS pada sistem pakar diagnosis penyakit gigi digunakan untuk mencari penyakit berdasarkan gejala-gejala yang diberikan oleh pengguna. Pseudo-code dari cara kerja Metode BFS disajikan pada Gambar 5:

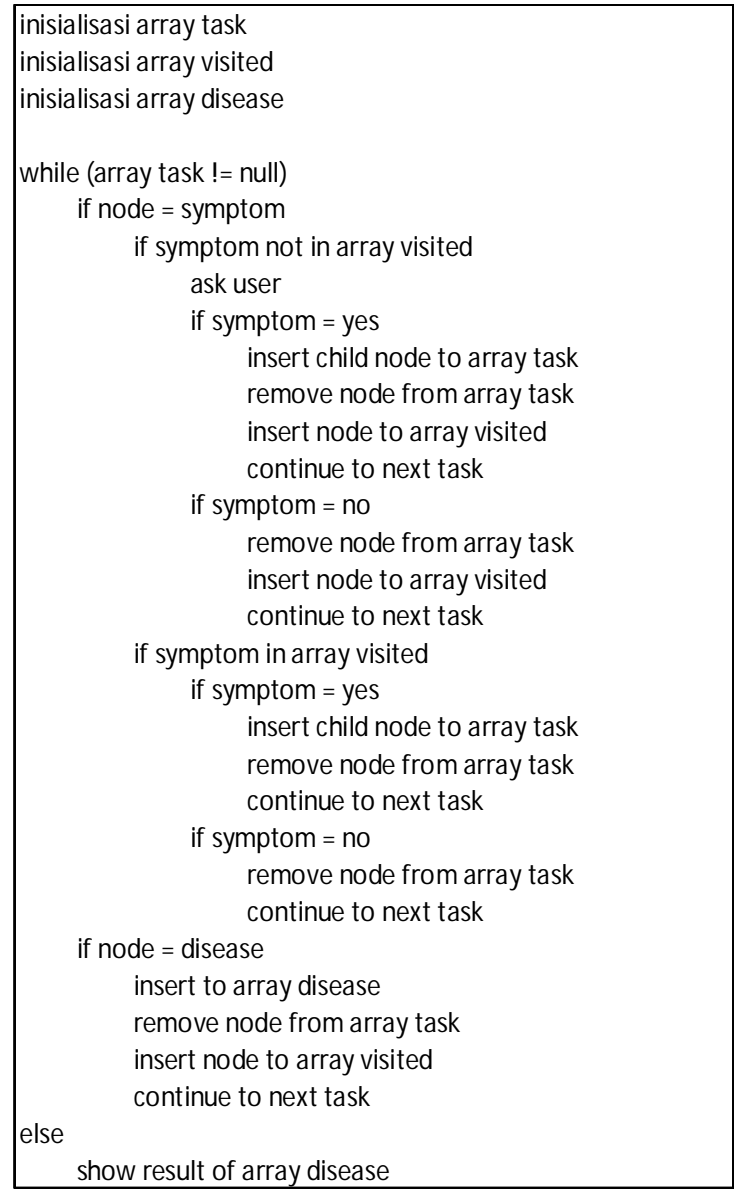

Gambar 5: Pseudo-code Breadth First Search
Pencarian penyakit dengan menggunakan Metode BFS dilakukan dengan menampilkan gejala satu per satu dalam satu tingkat secara horizontal pada pohon keputusan. Metode BFS memanfaatkan antrian untuk menyimpan node yang harus dikerjakan, jika node bernilai positif maka anak dari node tersebut ditambahkan ke antrian paling belakang. Pencarian akan menuju ke tingkat yang lebih dalam ketika semua node pada tingkat sebelumnya telah ditelusuri. Pencarian akan terus dilakukan sampai semua node yang bersangkutan berhasil ditelusuri.

\section{HASIL DAN PEMBAHASAN}

Hasil dan pembahasan berisi mengenai hasil uji coba dan kelebihan dari sistem pakar diagnosis penyakit gigi dengan Metode BFS berbasis instant messaging LINE Messenger.

\section{Uji Coba}

Uji coba sistem pakar yang dibangun pada penelitian ini dilakukan dengan melakukan interaksi dengan sistem pakar melalui instant messaging LINE Messenger untuk mencari penyakit berdasarkan gejala yang diberikan. Gambar 6 merupakan tampilan pengguna melakukan Add Bot sistem pakar dengan id : @526xyah.

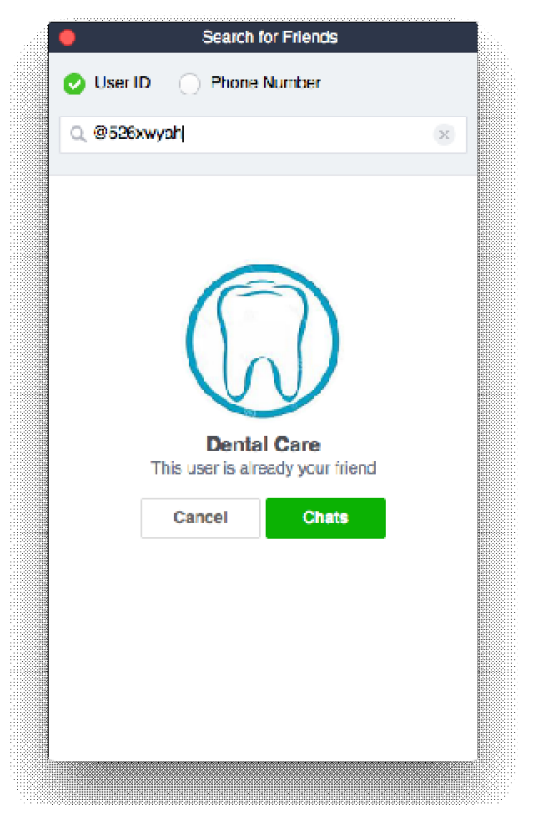

Gambar 6: Add Bot sistem pakar

Setelah melakukan add, klik Chats untuk memulai konsultasi. Gambar 7: merupakan tampilan saat pengguna baru memulai chat konsultasi dengan sistem pakar. Sistem akan mengiriman pesan sambutan berupa "Selamat datang di Dental Care Ketik 'Mulai' untuk memulai konsultasi'. Pengguna dapat mengawali dengan mengirim pesan 'Mulai' untuk memulai konsultasi.

Kadek Darmaastawan: Sistem Pakar Diagnosis Penyakit... 


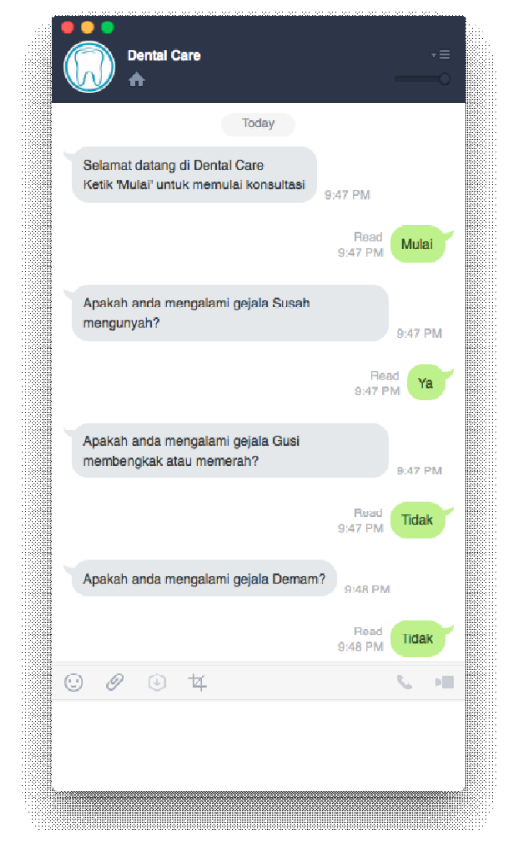

Gambar 7: Memulai interaksi dengan sistem pakar

Interaksi yang terjadi antara pengguna dengan sistem pakar adalah pengguna harus menjawab pertanyaan terkait gejala yang diberikan oleh sistem pakar dengan jawaban ' $Y a$ ' atau 'Tidak'. Jawaban tersebut akan menentukan jenis penyakit yang sedang dialami oleh pengguna berdasarkan gejalanya. Proses interaksi pada sistem pakar disajikan pada Gambar 8:

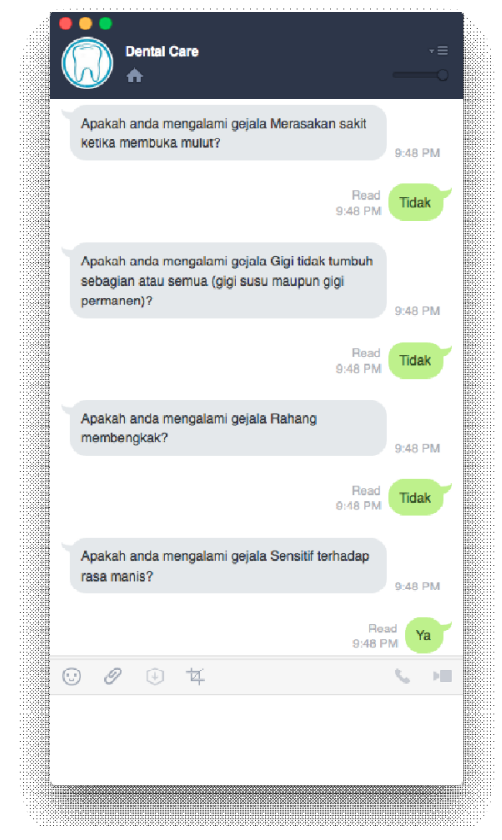

Gambar 8: Interaksi untuk mencari penyakit berdasarkan gejala

Sistem pakar akan menelusuri basis pengetahuan yang berbentuk pohon keputusan dengan Metode BFS. Pengguna akan diberikan pertanyaan terkait gejala, dimulai dari pohon keputusan tingkat pertama, kemudian dilanjutkan ke tingkat kedua, dan seterusnya. Sistem pakar akan melakukan penelusuran hingga penyakit ditemukan seperti yang dapat dilihat pada Gambar 9:

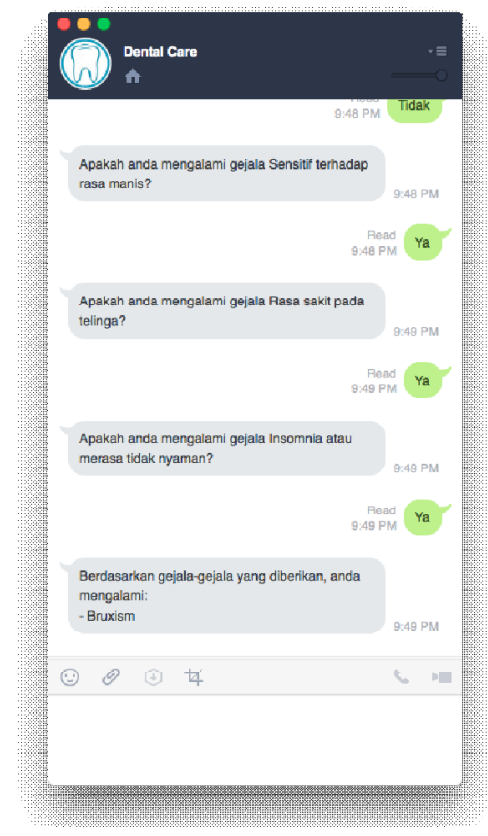

Gambar 9: Penyakit ditemukan

Gambar 10: merupakan tampilan saat sistem pakar sudah menelusuri semua pohon keputusan namun tidak menemukan penyakit berdasarkan gejala yang diberikan oleh pengguna.

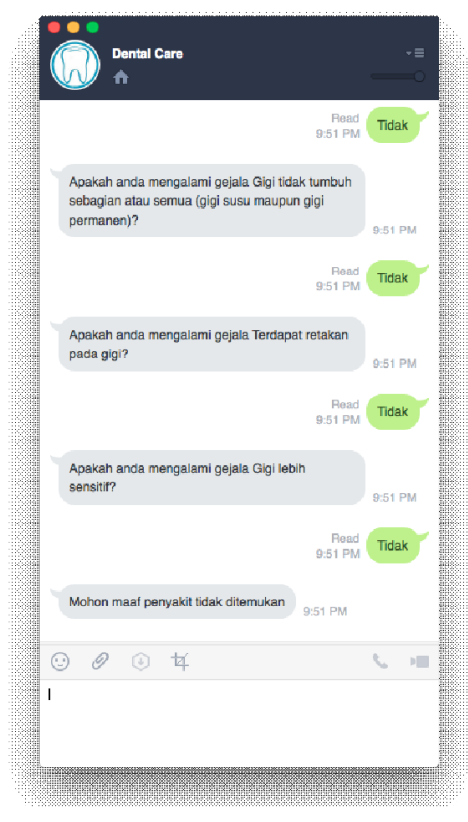

Gambar 10: Penyakit tidak ditemukan

Data hasil serangkaian uji coba interaksi pengguna dengan sistem pakar yang membuktikan bahwa sistem pakar sudah dapat berjalan disajikan pada Tabel 4 .

$$
\begin{gathered}
\text { TABEL IV } \\
\text { HASIL UJI COBA }
\end{gathered}
$$




\begin{tabular}{|c|c|c|c|}
\hline No & Pengguna & Gejala & Penyakit \\
\hline 1 & Lanang 1 & $\begin{array}{l}\text { - Susah mengunyah } \\
\text { - Sensitif terhadap rasa manis } \\
\text { - Rasa sakit pada telinga } \\
\text { - Insomnia atau tidak nyaman }\end{array}$ & Bruxism \\
\hline 2 & Lanang 2 & $\begin{array}{l}\text { - Terdapat retakan gigi } \\
\text { - Keberadaan gigi yang patah } \\
\text { - Dingin, manis, atau masam } \\
\text { menyebabkan rasa sakit } \\
\text { - Terdapat lubang pada gigi }\end{array}$ & Gigi patah \\
\hline 3 & Lanang 3 & $\begin{array}{l}\text { - Susah mengunyah } \\
\text { - Rahang membengkak atau } \\
\text { memerah } \\
\text { - Kelenjar getah bening } \\
\text { membengkak } \\
\text { - Sakit gigi atau berdenyut }\end{array}$ & $\begin{array}{l}\text { Abscess } \\
\text { Periapical }\end{array}$ \\
\hline 4 & Lanang 4 & $\begin{array}{l}\text { - Susah mengunyah } \\
\text { - Rahang membengkak atau } \\
\text { memerah } \\
\text { - Merasakan sakit ketika } \\
\text { membuka mulut } \\
\text { - Gusi atau gigi bernanah }\end{array}$ & $\begin{array}{l}\text { Abscess } \\
\text { Periodontal }\end{array}$ \\
\hline 5 & Lanang 5 & $\begin{array}{l}\text { - Gigi tidak tumbuh sebagian } \\
\text { atau semua (gigi susu } \\
\text { maupun gigi permanen) }\end{array}$ & Anodontia \\
\hline 6 & Lanang 6 & $\begin{array}{l}\text { - Gusi membengkak atau } \\
\text { memerah } \\
\text { - Nyeri di sekitar gusi } \\
\text { (disentuh maupun tidak } \\
\text { disentuh) } \\
\text { - Gusi atau gigi bernanah } \\
\text { - Luka atau kantung di antara } \\
\text { gigi dan gusi } \\
\text { - Gigi terlihat lebih panjang } \\
\text { dari biasanya } \\
\text { - Gigi goyah }\end{array}$ & Periodontitis \\
\hline 7 & Lanang 7 & $\begin{array}{l}\text { - Susah mengunyah } \\
\text { - Gusi membengkak atau } \\
\text { memerah } \\
\text { - Gigi lebih sensitif } \\
\text { - Bentuk gusi bundar } \\
\text { - Konsistensi gusi lunak }\end{array}$ & Gingivitis \\
\hline 8 & Lanang 8 & $\begin{array}{l}\text { - Gigi lebih sensitif } \\
\text { - Bentuk gigi tampak terkikis }\end{array}$ & Abrasi gigi \\
\hline 9 & Lanang 9 & $\begin{array}{l}\text { - Demam } \\
\text { - Gusi atau gigi bernanah } \\
\text { - Sakit gigi atau berdenyut } \\
\text { - Pipi membengkak }\end{array}$ & $\begin{array}{l}\text { Purulent } \\
\text { gigi }\end{array}$ \\
\hline 10 & Lanang 10 & $\begin{array}{l}\text { - Merasakan sakit ketika } \\
\text { membuka mulut } \\
\text { - Noda putih atau kecoklatan } \\
\text { pada permukaan gigi } \\
\text { - Permukaan gigi kasar }\end{array}$ & $\begin{array}{l}\text { Gigi } \\
\text { berlubang }\end{array}$ \\
\hline 11 & Lanang 11 & $\begin{array}{l}\text { - Susah mengunyah } \\
\text { - Rahang membengkak }\end{array}$ & $\begin{array}{l}\text { Tidak } \\
\text { ditemukan }\end{array}$ \\
\hline
\end{tabular}

Akurasi $=\frac{\text { Jumlah Percobaan Berhasil }}{\text { Jumlah Total Percobaan }} \times 100 \%$

Akurasi $=\frac{10}{11} \times 100 \%$

Akurasi $=90,9 \%$

Uji coba yang dilakukan menunjukkan dalam 11 kali percobaan, sistem pakar hanya mengalami sekali kegagalan atau tidak menemukan solusi. Kegagalan sistem pakar dalam menemukan penyakit disebabkan oleh pengguna yang memberikan gejala kurang lengkap dan tidak sesuai dengan basis pengetahuan seperti pada nomor 11 Tabel 4 .

\section{E. Kelebihan Sistem}

Sistem pakar diagnosis penyakit gigi dengan Metode BFS berbasis instant messaging LINE Messenger memiliki beberapa kelebihan.

1) Penerapan Instant Messaging LINE Messenger: Kelebihan atau keuntungan dari penerapan instant messaging LINE Messenger pada sistem pakar diagnosis penyakit gigi, yaitu:

- Waktu pengembangan yang tidak terlalu lama karena tidak perlu mengembangkan user interface,

- Dapat meminimalisir biaya server karena menggunakan server instant messaging LINE Messenger,

- Mudah dipublikasi karena menggunakan instant messaging LINE Messenger yang merupakan aplikasi yang cukup familiar pada masyarakat umum,

- Tidak memerlukan ruang penyimpanan tambahan pada smartphone pengguna apabila sudah memiliki instant messaging LINE Messenger.

- Mudah diakses kapan dan dimana saja.

2) Penggunaan Metode BFS: Kelebihan atau keuntungan penggunaan Metode BFS dalam melakukan pencarian penyakit pada sistem pakar diagnosis penyakit gigi, yaitu [32]:

- Pencarian dengan Metode BFS tidak pernah menemukan jalan buntu, kecuali semua node sudah ditelusuri dan gejala yang diberikan pengguna tidak ada yang sesuai dengan aturan basis pengetahuan,

Metode BFS akan menemukan solusi jika hanya terdapat satu solusi, namun jika terdapat lebih dari satu solusi, maka solusi minimum akan ditemukan.

\section{KESIMPULAN}

Sistem pakar diagnosis penyakit gigi berbasis instant messaging LINE Messenger telah berhasil dibuat pada penelitian ini. Penerapan instant messaging LINE Messenger dalam membangun sistem pakar memberikan dampat positif berupa hemat biaya dan waktu pengembangan. Dampak lain penerapan instant messaging LINE Messenger adalah sistem pakar mudah digunakan kapan dan dimana saja karena instant messaging LINE Messenger adalah aplikasi yang umum di masyarakat. Masyarakat umum juga tidak memerlukan ruang penyimpanan lebih pada smartphone untuk dapat menggunakan sistem pakar. Sistem pakar diagnosis penyakit 
gigi yang dibangun pada penelitian ini menggunakan Metode BFS dalam melakukan pencarian penyakit berdasarkan gejala yang diberikan pengguna. Penggunaan Metode BFS mengakibatkan sistem pakar tidak pernah menemukan jalan buntu, kecuali semua node telah ditelusuri dan gejala yang diberikan oleh pengguna tidak ada yang sesuai dengan aturan basis pengetahuan. Uji coba menunjukkan sistem pakar memiliki tingkat akurasi sebesar 90,9\%. Hal tersebut menunjukkan sistem pakar berbasis instant messaging merupakan sebuah solusi alternatif dalam mengembangkan sistem pakar karena memudahkan proses pengembangan, namun tetap menjaga kualitas dan akurasi sistem pakar tersebut. Penelitian lebih lanjut perlu dilakukan untuk meningkatkan kinerja dari sistem pakar, seperti menambah jenis instant messaging untuk menambah cakupan pengguna. Pengembangan lebih lanjut lainnya adalah dengan menambahkan gejala dan penyakit gigi sehingga sistem pakar dapat mengetahui lebih banyak penyakit gigi.

\section{REFERENSI}

[1] A. Khanna, B. Pandey, K. Vashishta, K. Kalia, B. Pradeepkumar, and T. Das, "A Study of Today's A.I. through Chatbots and Rediscovery of Machine Intelligence," Int. J. u-e-Service, Sci. Technol., vol. 8, no. 7, pp. 277-284, 2015.

[2] Adriyendi, "INFERENCE MENGGUNAKAN FORWARD CHAINING PADA FOOD AFFORDABILITY," J. Sainstek, vol. 9, no. 2, pp. 108-122, 2017.

[3] I. N. S. Yasa, I. K. G. D. Putra, and N. M. A. E. . Wirastuti, "Peramalan Kurs Rupiah Terhadap US Dollar Menggunakan Metode Hibrid," Maj. Ilm. Tekologi Elektro, vol. 16, no. 3, pp. 33-38, 2017.

[4] P. R. Nurbhawa, I. K. G. D. Putra, and N. Gunantara, "Sistem Pendukung Keputusan Untuk Penentuan Lokasi BTS PT . Smartfren Menggunakan Metode Fuzzy -AHP," Maj. Ilm. Tekologi Elektro, vol. 16, no. 3, 2017 .

[5] Olanloye and D. Odunayo, "AN EXPERT SYSTEM FOR DIAGNOSING FAULTS IN MOTORCYCLE," Int. J. Eng. Appl. Sci., vol. 5, no. 06, pp. 1-8, 2014.

[6] W. U. Setiabudi, E. Sugiharti, and F. Y. Arini, "Expert System Diagnosis Dental Disease Using Certainty Factor Method," Sci. J. Informatics, vol. 4, no. 1, pp. 43-50, 2017.

[7] N. L. Ratniasih, M. Sudarma, and N. Gunantara, "Penerapan Text Mining dalam Spam Filtering untuk Aplikasi Chat," Maj. Ilm. Tekologi Elektro, vol. 16, no. 3, 2017.

[8] J. Clement, "Most famous social network sites 2019, by active users," 2019. https://www.statista.com/statistics/272014/global-socialnetworks-ranked-by-number-of-users/ (accessed May 27, 2020).

[9] F. Zebua, "Laporan DailySocial: Survey Instant Messaging 2017," 2017. https://dailysocial.id/post/laporan-dailysocial-survey-instantmessaging-2017 (accessed May 27, 2020).

[10] LINE Messenger Corporation, "LINE Download," line.me https://line.me/en-US/download (accessed May 30, 2020).

[11] LINE Messenger Corporation, "Messaging API Reference," line.biz. https://developers.line.biz/en/reference/messaging-api/ (accessed May 30, 2020).

[12] K. Darmaastawan, I. M. Sukarsa, and P. W. Buana, "LINE Messenger as a Transport Layer to Distribute Messages to Partner Instant Messaging," Int. J. Mod. Educ. Comput. Sci., vol. 11, no. March, pp. 1-9, 2019, doi: 10.5815/ijmecs.2019.03.01.

[13] K. T. Wirawan, I. M. Sukarsa, and I. P. A. Bayupati, "Balinese Historian Chatbot using Full-Text Search and Artificial Intelligence Markup Language Method," I.J. Intell. Syst. Appl., vol. 11, no. 8, pp. 21-34, 2019, doi: 10.5815/ijisa.2019.08.03.

[14] I. M. Sukarsa, I. K. G. D. Putra, N. P. Sastra, and L. Jasa, “A New Framework for Information System Development on Instant Messaging for Low Cost Solution," TELKOMNIKA, vol. 16, no. 6, pp. 2799-2808, 2018, doi: 10.12928/TELKOMNIKA.v16i6.8614.
[15] D. A. K. Arimbawa P, I. K. G. D. Putra, and I. M. Sukarsa, "Library System Using Radio Frequency Identification ( RFID ) and Telegram Bot API," Lontar Komput., vol. 9, no. 1, pp. 40-51, 2018.

[16] D. Namiot, "Twitter as a transport layer platform," Proceding 2015 IEEE Artif. Intell. Nat. Lang. Inf. Extr. Soc. Media Web Search Fruct Conf. (AINL-ISMW Fruct., pp. 46-51, 2015, doi: 10.1109/AINLISMW-FRUCT.2015.7382968.

[17] M. News, "Born from Japan disasters, Line app sets sights on U.S., China," reuters.com, 2012. https://www.reuters.com/article/japan-appline/born-from-japan-disasters-line-app-sets-sights-on-u-s-chinaidUSL2E8JD0PZ20120816 (accessed May 27, 2020).

[18] LINE Messenger Corporation, "Getting started with the Messaging API," line.biz. https://developers.line.biz/en/docs/messagingapi/getting-started/\#creating-a-channel (accessed May 30, 2020).

[19] A. A. Pramesti, R. Arifudin, and E. Sugiharti, "Expert System for Determination of Type Lenses Glasses using Forward Chaining Method," Sci. J. Informatics, vol. 3, no. 2, 2016, doi: 10.15294/sji.v3i2.7914.

[20] M. A. Muslim, I. Kurniawati, and E. Sugiharti, "EXPERT SYSTEM DIAGNOSIS CHRONIC KIDNEY DISEASE BASED ON MAMDANI FUZZY INFERENCE SYSTEM," J. Theor. Appl. Inf. Technol., vol. 78, no. 1, 2015.

[21] H. A. Al Rekhawi, A. A. Ayyad, and S. S. A. Naser, "Rickets Expert System Diagnoses and Treatment," Int. J. Eng. Inf. Syst., vol. 1, no. 4, pp. 149-159, 2017.

[22] S. S. A. Naser, M. Z. Shaath, and Abstract, "Expert system urination problems diagnosis," World Wide J. Multidiscipl Ina. Res. Dev. WWJMRD, vol. 2, no. 5, pp. 9-19, 2016.

[23] S. S. A. Naser and M. M. Hilles, "An expert system for shoulder problems using CLIPS," World Wide J. Multidiscipl Ina. Res. Dev. WWJMRD, vol. 2, no. 5, pp. 1-8, 2016.

[24] R. A. Sihombing, "Sistem pakar untuk mendiagnosa gangguan pada sistem hepatobiliaris berbasis android mobile," J. Satuan Tulisan Ris. dan Inov. Teknol., vol. 3, no. 1, pp. 98-106, 2018.

[25] H. Agung and N. Y. Marselinus, "Implementasi Metode Breadth First Search dan Vikor pada Aplikasi Diagnosa Kerusakan Hardware Komputer," J. SISFOKOM, vol. 05, no. 1, pp. 46-53, 2016.

[26] C. Tonyjanto, "SISTEM PAKAR MENGIDENTIFIKASI PENANGGULANGAN PENYAKIT PADA GIGI DAN MULUT," $J$. Teknol. Inf. dan Komput., vol. 1, no. 1, 2015.

[27] Y. Efendi, "Diagnosis Kanker Darah pada Anak menggunakan Inferensi Forward Chaining," SATIN - Sains dan Teknol. Inf., vol. 2, no. 1, pp. 1-6, 2016.

[28] Y. A. Pratama and E. Junianto, "Sistem Pakar Diagnosa Penyakit Ginjal Dan Saluran Kemih Dengan Metode Breadth First Search," J. Inform., vol. 2, no. 1, 2016, doi: 10.31311/ji.v2i1.69.

[29] R. Handayani, "METODA BREADTH FIRST SEARCH PADA INFERENSI FORDWARD CHAINING UNTUK MENDIAGNOSA HAMA TANAMAN JERUK," J. KomTekInfo, vol. 4, no. 2, pp. 241249, 2017.

[30] I. M. Sukarsa, N. W. Wisswani, T. Pustaka, and S. Pakar, "RANCANG BANGUN SISTEM PAKAR UNTUK PERBAIKAN KECEPATAN DAN KEGAGALAN KONEKSI PERALATAN EKSTERNAL PADA PERSONAL KOMPUTER," Maj. Ilm. Teknol. Elektro, vol. 8, no. 1, 2012, [Online]. Available: https://ojs.unud.ac.id/index.php/JTE/article/view/1574/920.

[31] R. Rahim et al., "Congklak, a traditional game solution approach with breadth first search," in MATEC Web of Conferences 197, 2018, vol. 03007, pp. 1-4.

[32] R. Ratnadewi, E. M. Sartika, R. Rahim, B. Anwar, M. Syahril, and H. Winata, "Crossing Rivers Problem Solution with Breadth-First Search Approach," in The 2nd Annual Applied Science and Engineering Conference (AASEC 2017), 2017, vol. 288, no. 1, doi: 10.1088/1757899X/288/1/012125.

[33] M. J. Pathak, R. L. Patel, and S. P. Rami, "Comparative Analysis of Search Algorithms," Int. J. Comput. Appl., vol. 179, no. 50, pp. 40-43, 2018.

[34] K. W. A. S, P. D. Kusuma, C. Setianingsih, and A. W. Pollution, "Monitoring and Classification System of River Water Pollution Conditions with Fuzzy Logic," pp. 112-117, 2019. 